\title{
УЧАСТЬ МЕДИЧНОЇ СЕСТРИ В РАННІЙ ДІАГНОСТИЦІ ЗЛОЯКІСНИХ НОВОУТВОРЕНЬ ТА ДОГЛЯД ЗА ОНКОХВОРИМИ В ЛІКАРНІ ТА ВДОМА
}

\author{
А. Л. Орленко, П. І. Бучко, П. Б. Фундитус \\ Чортківський державний медичний коледж
}

\begin{abstract}
У статті висвітлено роль медичної сестри у ранній діагностиці злоякісних новоутворень, їі дії та основні принципи догляду за пацієнтами з онкологічними захворюваннями в закладах охорони здоров'я та в домашніх умовах.
\end{abstract}

\section{PARTICIPATION OF NURSES IN THE EARLY DIAGNOSIS OF MALIGNANT TUMORS AND CARE OF CANCER PATIENTS IN THE HOSPITAL AND AT HOME}

\author{
A. L. Orlenko, P. I. Buchko, P. B. Fundytus
}

Chortkiv State Medical College

The article deals with the role of nurses in the early diagnosis of malignant tumors, their actions and the basic principles of caring for patients with cancer in health care facilities and at home.

«Хто інформований - той озброєний»

Вступ. Кожна професійна медсестра має певну відповідальність у боротьбі з раком. Вона має брати активну участь у пропаганді здорового способу життя та навчанні основ догляду за онкологічними хворими в закладах охорони здоров'я, підприємствах іприватних структурах. Дані з 1934 року вказують на постійне збільшення смертності населення від злоякісних новоутворень, і на сьогодні рак займає друге місце серед причин смертності в Україні. Згідно із сучасними статистичними данимикожна четверта людина незалежно від віку чи статі хворіє на рак. Онкологічні захворювання $\epsilon$ провідною причиною смертності дітей віком до 15 років і жінок віком від 35 до 55 років. Чоловіки частіше помирають від цієї недуги, ніж жінки. Двадцять п'ять років тому, виживання складало $35 \%$, 3 більш ранньою діагностикою і лікуванням смертність зменшилась до $20 \%$. У 2013 році більшість чоловіків, які померли через рак, мали ураження травного тракту, в тому числі шлунка, $37,5 \%$ - дихальної системи, в тому числі $20 \%$ -

(С) А. Л. Орленко, П. І. Бучко, П. Б. Фундитус, 2014 легень і гортані, та 10,7 \% - передміхурової залози. У жінок, які померли від раку, реєстрували пухлини такої локалізації: травного тракту, в тому числі шлунка - 33,7\%, статевих шляхів - 20,1\% і грудей - $19,0 \%[1,3]$.

Основна частина. Якими повинні бути діїмедсестри? Працюючи із людьми своєї дільниці, медична сестра розпізнає потенційного хворого на рак, людину з підозрілими ознаками чи симптомами злоякісних захворювань, пацієнта, якого лікують або завершили лікування, і хворого на рак у запущеній стадії. Кожна група становить інтерес для медсестри. Освітні зусилля спрямовані на раннє виявлення потенційної групи та проведення профрілактичних заходів (медичних оглядів). Надзвичайно важливим $є$ мотивувати громадян прислухатися до небезпечних сигналів і заохочувати їх щорічно проходити профілактичні медичні огляди!

Медсестра може пояснити та допомогти жінкам у подоланні страху перед оглядом та виконанням деяких діагностичних процедур. $\mathrm{Ha}$ 
приклад: інформувати, що цитологічне дослідження - метод отримання вагінального мазка, який використовується для раннього виявлення раку шийки матки - є процедурою безболісною, і що гінекологічний огляд важливий для ранньоїдіагностики раку. Якщо медичне товариство схвалює - медична сестра може використовувати, як методи для переконання пацієнтів, медичні фільми, покази слайдів із різними клінічними випадками, які закінчились трагічно для пацієнтів завдяки їхньому нехтуванні профілактичними оглядами і самообстеженням. Деякі люди можуть не знати про підозрілі ознаки і симптоми раку, тож такі лекції та бесідиє достатньо ефективними. Іноді недостатнє або незадовільне медичне обслуговування може бути причиною страху перед діагнозом рак.

Медсестра повинна розпізнавати симптоми, застосовуючи ії базові знання з онкологіі. Налагоджуючи хороші відносини з пацієнтом і будучи хорошим слухачем, медична сестра може виявити інформацію про ознаки і симптоми, які можуть здатися неважливими для пацієнта. Цими, здавалося 6 незначними симптомами або ознаками можуть бути: пухлина в груді, яка не викликає болю; кровотеча або кров'янисті виділення між менструаціями тощо.

Догляд за онкохворими в лікарні. Операційні втручання, що виконуються з приводу пухлин, досить травматичні. Пацієнти похилого і старечого віку, як правило, мають ряд супутніх захворювань. Тому велике значення надається догляду за хворими в післяопераційному періоді.

Залежно від загального стану хворого, виду знеболювання, особливостей операції і спеціальних вказівок лікаря, медична сестра забезпечує певне положення хворого в ліжку.

У перші години після наркозу, до появи чітких ковтальних рефлексів і відновлення тонусу мускулатури, не потрібно піднімати голову хворого (для запобігання западанню язика). У разі необхідності доцільно ввести повітровід. Пробудження хворих може супроводжуватись блюванням. Для профілактики аспірації блювотних мас потрібно повернути голову набік, очистити рот серветкою або відсмоктувачем. Медична сестра повинна спостерігати за зовнішнім виглядом хворого, за пульсом, вимірювати артеріальний тиск, стежити за диханням, сечовипусканням, а також за станом пов' язки. Різке зниження артеріального тиску, що супроводжується пришвидшенням пульсу, холодним потом, блідістю, частим поверхневим диханням, може бути проявом післяопераційного шоку, кровотечі, гострої серцево-судинної недостатності та недостатності надниркових залоз. Помітивши такі симптоми, медична сестра зобов'язана викликати лікаря, який призначить відповідне лікування.

Якщо під час наркозу застосовувались міорелаксанти, то можлива пізня зупинка дихання (рекураризація). Хворий стає в'ялим, не може підняти руку, дихання стає поверхневим. У таких випадках необхідна штучна вентиляція легень.

Для зменшення болю після операції застосовують наркотичні аналгетики, дія яких триває протягом 4-5 годин. Якщо вводити їх чітко по годинах, то пацієнта можна захистити від болю майже повністю.

У першу добу після операції необхідний постійний контроль за станом пов'язки, кількістю і характером виділень з рани. Якщо в рані залишені дренажі, тампони і очікується просякання пов'язки, необхідно попередити про це хворого і вжити заходів для попередження забруднення білизни виділеннями $з$ дренажів. При значному просяканні пов'язки, особливо кров'ю, медична сестра зобов'язана повідомити про це лікаря.

Особлива увага надається дихальній і лікувальній гімнастиці. Хворому пропонують періодично відкашлюватись, притримуючи ділянку рани рукою, здійснювати щогодини по 8-10 глибоких дихальних рухів, надувати повітряні кульки тощо. Застосування лікувальної гімнастики сприяє відкашлюванню харкотиння, посилює кровообіг у легенях, а також значно покращує їх вентиляцію.

Онкологічним хворим категорично протипоказані теплові процедури (гірчичники, компреси), оскільки це призводить до посилення росту пухлини.

Для розрідження харкотиння і швидшого видалення його під час кашлю застосовують лужні інгаляції з трипсином, хімотрипсином. Це сприяє зняттю больового синдрому і доброму відкашлюванню. За можливості, якомога раніше хворого піднімають з ліжка.

Онкологічні хворі мають схильність до тромбоутворення. Активний спосіб життя пацієнта покращує кровообіг, зменшує можливість утворення тромбів. Для профілактики цих ускладнень в день операції вводять антикоагулянти прямої дії (гепарин - по 5000 ОД 4 рази на добу; фраксипарин 1 доза на добу).

Тромбофлебіт може уражати глибокі та поверхневі вени. Хворі скаржаться на біль у кінцівці, набряк, появу щільних болючих тяжів по 
ходу вен. Особливо небезпечний тромбоз глибоких вен. Тромб, який утворився у вені, відірвавшись, 3 течією крові може потрапити в легеневу артерію і спричинити емболію ї̈ основного стовбура. Дрібніші тромби стають причиною інфаркту легень. Скарги на біль і швидко зростаючий набряк кінцівки повинні насторожити медичну сестру. Хворому призначають суворий ліжковий режим. Лікування тромбофлебіту зводиться до надання кінцівці підвищеного положення, накладання компресів з маззю Вишневського або гепариновою маззю. Застосовуються також антикоагулянти, антибіотики, антиагреганти (аспірин, курантил) та постійний контроль за показниками згортальної системи крові.

Догляд за пацієнтами вдома. Небезпечним ускладненням яке може очікувати пацієнта вдома $є$ поява пролежнів. Частіше вони утворюються в ділянках крижів, лопаток, кутів ребер, відростків хребців. Сприяє їх утворенню тиск на шкіру, вологість і забруднення шкіри. Ранні ознаки пролежнів - почервоніння і болючість шкіри, потім - мацерація ураженої ділянки, утворення виразок. Пролежні нерідко стають причиною різкого погіршення стану хворого, а іноді призводять до смерті від сепсису. Для попередження пролежнів медична сестра повинна розповісти i навчити рідних пацієнта: своєчасно розгладжува-

\section{ЛІТЕРАТУРА}

1. Михайлович Ю. Й. Організація протиракової боротьби / Ю.Й. Михайлович, А.В. Гайсенко // Клінічна онкологія. - 2011. - № 2 (2). - С. 47-48.

2. Ковальчук Л. М. Медсестринство в онкології / Л. М. Ковальчук. - К. : Медицина, 2011. - С. 19-20, 95-99. ти складки білизни, змінювати положення хворого в піжку, протирати шкіру камфорним спиртом, підкладати під крижі та лопатки гумові та ватномарлеві круги і акцентуватина тому, що пролежні значно легше попередити, ніж лікувати.

Тяжкохворим необхідно двічі на день проводити туалет порожнини рота і зубів антисептичним розчином (2 \% розчин гідрокарбонату натрію, розчин фурациліну), після чого рот прополіскують теплою водою.

У похилому і старечому віці після операцій на органах черевної і грудної порожнин при тривалому ліжковому режимі важливу роль відіграють активна поведінка хворого, часта зміна положення, загальний масаж тіла, призначення бронхолітичних, серцево-судинних засобів та ін.

Висновки. Медична сестра має брати активну участь у навчанні, санітарно-просвітницькій роботі, пропаганді в суспільстві здорового способу життя та догляду за онкологічними хворими. Медсестра має бути сумлінною і уважною при виконанні своїх обов'язків, адже помилки при виконанні процедур, введенні ліків можуть призвести до тяжких ускладнень, а недостатній догляд навіть до смерті хворого. Від того, як медсестра оглядає пацієнта, робить ту або іншу процедуру, у багатьох випадках залежить успіх ранньої діагностики та вчасного лікування онкохворого.

3. http://www.cancer.ic.ck.ua/u_index_7_8.htm

4. http: //www.cancer.ic.ck.ua/u index 7.htm 